\title{
Unlimited, Unseen and Unveiled: The Force of the Aorist in Pascal Quignard's Sur le jadis
}

\section{Citation}

Hamilton, John T. 2012. "Unlimited, Unseen and Unveiled: The Force of the Aorist in Pascal Quignard's Sur Le Jadis." L'Esprit Créateur 52 (1): 96-106.

\section{Published Version}

https://muse.jhu.edu/journals/lesprit_createur/v052/52.1.hamilton.pdf

\section{Permanent link}

http://nrs.harvard.edu/urn-3:HUL.InstRepos:12560999

\section{Terms of Use}

This article was downloaded from Harvard University's DASH repository, and is made available under the terms and conditions applicable to Open Access Policy Articles, as set forth at http:// nrs.harvard.edu/urn-3:HUL.InstRepos:dash.current.terms-of-use\#OAP

\section{Share Your Story}

The Harvard community has made this article openly available.

Please share how this access benefits you. Submit a story.

\section{Accessibility}


John T. Hamilton

Unlimited, Unseen and Unveiled:

The Force of the Aorist in Pascal Quignard's Sur le jadis

\author{
Contrast is everywhere. One has only to take note of it. \\ Similarity is hidden; it must be sought out, and it is found \\ only after the most exhaustive efforts. \\ Stravinsky, Poetics of Music \\ —Jadis, si je me souviens bien [...] \\ Rimbaud, Une Saison en Enfer
}

The five volumes that comprise Pascal Quignard's Dernier royaume, published 2002 - 2005, are in some respects typical. They rehearse, elaborate and modify themes and motifs long familiar from the author's considerable œuvre. Irretrievable loss and transience; silence and the human voice; uterine existence and birth; rhetoric, reading, and musical resonance; horror, nakedness and the constitutive secret — all surge forth over the course of these books, formulated in Quignard's usual kaleidoscopic and aphoristic style. As expected, deeply personal reflections and autobiographical details commingle with obscure allusions, provocative etymologies and peculiar anecdotes drawn from the full range of the world's nearly forgotten cultural legacies. As 
expected, the accumulated material is presented in verbal mosaics that closely reflect Quignard's creative, wandering abandonment, his renunciation of mastery, his attentive submission to texts, history and memory. For Quignard's devoted readers, both the form and content of Dernier royaume amount to a return to the same, a restitution of the similar, something at once new yet not without a haunting sense of déjà lu.

That is not to say, however, that Quignard's pentalogy has simply succumbed to a flat, stylistic homogeneity; that the work has fallen into a self-scripted routine. Although the terrain may be familiar, it is in no way comforting or reassuring. On the contrary, it affords the recognition of the disruptive power of the same. As Quignard has persistently demonstrated, the return to the same hardly offers respite; for the familiar is often the harbor for that which at any moment may surge forth with frightening force. Like Freud's Heimliche, the familiar may be the secret (heimliche, geheime) container of das Unheimliche, the uncanny, l'inquiétante étrangeté. With Quignard, as in the Freudian model, the return to the same may always be but a cover for the return of the repressed. Indeed, Freud's well-known "repetition compulsion," which unconsciously drives him again and again to the same sordid neighborhood of Rome, shares many analogous traits with Quignard's sordidissimes, those pieces rejected or "abjected" from the literary-philosophical canon which ceaselessly attract the author's concern. ${ }^{1}$ Yet, where Freud sees a symptom, Quignard discovers a method; where psychoanalysis works toward a cure, Quignard works on registering the incurable. While Freud approaches the unconscious in order to master it and thereby put life back into working order, Quignard attends to what has almost been obliterated in order to rescue it and thereby bring his writing back to life. ${ }^{2}$

This salvific program is explicitly expressed in the note Quignard appended to the back cover of his Petits traités: 
[Les Petits traités] étaient de courts arguments déchirés, des contradictions laissées ouvertes, des mains négatives, des apories, des fragments de contes, des vestiges. Je ne retenais que ce qui du temps était rejeté par l'Histoire tandis qu'elle prétendait écrire sa grande narration mensongère. Je ne retenais des livres des Anciens que ce que la Norme expulsait des littératures du passé pour asseoir son autorité collective et académique. ${ }^{3}$

Jean-Louis Pautrot refers to this text and comments: "Ce geste annoncé pour les Petits traités informe l'œuvre. Les exclus de l'Histoire, dont les travaux ne firent 'pas une ride sur la surface du temps,'coupables de singularité pour leur époque, sont innocents de la doxa. ${ }^{, 4}$ Needless to say, in order for these rejected, paradoxical pieces to have an effect, it is necessary to present and maintain the frame of doxa, which serves as foil for the resurgence of the expelled. ${ }^{5}$ The abnormal can only be defined as such in relation to the norm. Counter currents require something to counter. Could one, then, not argue that the typical form and content of Quignard's later work, particularly in Dernier Royaume, constitutes a familiar, more or less expected setting for staging the reappearance of the unexpected? Or is it not rather the case that the return to the same, the realm of the similar, is coincident with the return of the suppressed? That the unexpected is nothing but the expected viewed from a new perspective? Does Quignard's stated distinction from collective and authoritative authorities not already suggest that he simply sees or strives to see "the same" in a truly different way? An adequate response to these questions would have to rest on how we read this simplicity.

A particularly rich example, which might address the problem, comes straight away on the very first page of Sur le jadis, the second volume of the Dernier royaume series. With the opening sentence, Quignard describes a very recent walk through the mountainous regions of 
Haute Provence: "Hier je suis descendu au fond du vallon sous le causse qui prolonge le lac de Garet.”

Cela faisait vingt-deux ans que j'évitais cet amas de pierres en ruine qui étaient entourées d'herbes folles et de mousses. De ronciers. [...]

Je ne pus m'empêcher de me dérouter de mon chemin. J'avais encore envie de voir. Je voulus y jeter les yeux un instant. J'entrai sans le pouvoir tout à fait. Ma gorge se serre. J'ai un léger vertige. Je ressors presque aussitôt. ${ }^{6}$ As my epigraph reminds us, where Rimbaud opens his descent by turning to the Jadis, Quignard begins his reflections "on the Jadis" with a descent. ${ }^{7}$ Analogous to Rimbaud's hesitant—-hellish, damning—qualification ("si je me souviens bien"), Quignard's experience is fraught with ambivalence: the return to the same, to a place visited over twenty years before, is in fact a return to an old evasion, to something once suppressed; the will to self-prevention or self-preservation is weakened, yet the desire to carry on is checked by some fundamental incapacity. The repeated confrontation suddenly causes dizzyness, which goads him to leave almost immediately.

The fact that this scene confronts an old avoidance and presents a vague but powerful resurgence only partially explains the force of this brief, opening narration. A far greater nuance rests in the shifting verb morphology, which will allow this incipit or re-commencement to be taken as programmatic for the present reading of Sur le jadis. The text quickly runs through an entire range of tenses: the passé composé ("Je suis descendu"); the imparfait ("Cela faisait," “j’évitais"); the passé simple (“Je ne pus," "Je voulus," “J'entrai”); before moving directly into the présent: "Ma gorge se serre. J'ai un léger vertige. Je ressors presque aussitôt." How should we account for this confusion des temps? 
Tense shifting, especially from the past to the present, is generally understood as a deictic gesture, one that achieves an effect of vividness, referred to in Greek poetics as enargeia and in Latin variously as illustratio, evidentia, or demonstratio. ${ }^{8}$ With the sudden intrusion of the present tense, the story is no longer felt to be a story but rather an event unfolding in the here and now. Distance is overwhelmed. The scene demands alertness. What this vividness entails, it should be specified, is nothing less than language's readiness to disappear, to allow its words and voice to yield its place to the vision it evokes. The medium hides its mediating role. The listener or reader becomes a spectator, a participant in the scene, an engaged witness; and the statement thereby acquires greater force, more urgency. To employ the terms famously defined by Émile Benveniste, the histoire - the story given without indication to the context of its telling - abruptly turns into a discours, marked by personal pronouns and verbal tenses that allude to the narrating act. $^{9}$

The technique is discernible throughout classical literature, for example in the following pasage from Vergil's Aeneid:

vix prima inceperat aestas

et pater Anchises dare fatis vela iubebat.

litora cum patriae lacrimans portusque relinquo

$$
\text { (Aen. } 3.8-10)
$$

The onset of summer hardly had begun and father Anchises ordered to set sails to the fates, when I leave my country's shores and harbors, crying My literal translation of the verb tenses should emphasize the effect. From a purely grammatical point of view, we would expect the coordination of the pluperfect (inceperat) and the imperfect 
(iubebat), where the former supplies information that situates the narration in the past. The pluperfect and the imperfect work together to maintain that this is an histoire that has taken place sometime beforehand. The subsequent inrusion of the present tense (relinquo) appears to pull the narration out of the past, effacing the distance that separates the temps de l'énoncé and the temps de l'énonciation. Traditionally, philologists would classify this use as the "historical present" (praesens historicum), which appears to heighten dramatic tension. ${ }^{10}$ In considering modern usage, some linguists explain that the contrast distinguishes background from foreground material. ${ }^{11}$ In this brief example from the Aeneid, the shift from past to present tenses would simply mark the summer's onset and Anchises command as non-events that provide background to the event of Aeneas's lacrymose departure. Other language scholars would regard Vergil's tense shifting as a progression from a more static, depictive narration toward an increased dynamism. ${ }^{12}$

All of these interpretations of the role of the present in past narration are compelling and have at least some bearing on the opening sequence in Sur le jadis. The non-event of a hike through Haute Provence, the background experience of returning to the same, could indeeed be read as preparation for the impingement of a powerful event. Yet, as we continue to read, we see that Quignard complicates any straightforward account by imposing even further shifs in tense:

Ma gorge se serre. J'ai un léger vertige. Je ressors presque aussitôt.

Mes yeux se portèrent d'eux-mêmes près de l'autel des Romains.

Je ne vis rien. Rien ne se leva, venant d'autrefois. $(S J 9-10)$

The reintroduction of the passé simple ("se portèrent," "vis," "se leva") would appear to expel the scene back into a prior time, reducing the vertiginous discours back into a mere histoire. The foreground seems to dissolve into the background. As the passage continues, 
however, it becomes quite clear that the move back to the past tense hardly diminishes the effect of vividness or dramatic tension: "Dans l'ombre de la branche je vis surgir soudain le visage d'une femme" (SJ 10-11). The suddenness that modifies the passé simple disproves the claim that the present tense alone can communicate intensity. In fact, restricting vivid effects exclusively to the present tense and denying the past tense this power would only be valid if we read the verbs as expressing time alone and thus ignore their qualities of aspect. Like all IndoEuropean languages, modern French verbs exhibit aspect (continuous, completed, or aorist), even if these assignations are no longer assigned unequivocally. Rather than take the shift from the present to the past as conversion of discours to histoire, it would be better to understand it as a modulation from continuous to simple or aorist aspect, from an on-going situation to one that occurs forcefully "at once."

A reading of Sur le jadis should reveal that aspectual difference plays a central role not only in the book's stylistic presentation but also in its thematic organization. As the title already suggests, the volume is not only a study of time but more precisely a study of temporal aspects. In brief, to approach Sur le jadis critically is to witness and assess what happens when a particular species of time, the ongoing now of writing and reading, intersects or collides with another kind of time, the completeness of a past conceived as space. To employ Latin terms: Sur le jadis performs the dynamic encounter between the infectum of the now and perfectum of the historical past. Moreover, and even more crucially, the book grapples to express the ground or foundation of this temporal confrontation. It attempts to evoke that which makes this concurrence possible. In reaching for this potentiating origin, this potent source of temporal experience, we need to have recourse to the third verbal aspect — the one that attracts Quignard's 
attention above all—namely the already or iam that characterizes the simple aspect discernible in the Greek aorist.

Early on in Sur le jadis, Quignard confirms the completed, spatial quality of History ("Histoire") by reconnecting the word page (or pagina) with pagus ("country, pays"): "la demeure la plus vaste où l'âme puisse se mouvoir, voyager, comparer, revenir” (SJ 17). By means of the written word, temporal experience is transformed into a landscape open to repeated visits and return engagements. The page, and this would of course include Quignard's pages, invites exploration, or better, in-vestigation; it is the past as a "nouvel espace" where vestiges of absent presence are accessible to the present eye: "Le passé est un immense corps dont le présent est l'œil" (SJ 20). ${ }^{13}$ A broad horizon stretches out before the journeying spectator. History is there as that which has taken place. It is complete. The present - the present time of writing, the present now of reading — penetrates the surrounding space of complete, perfected history; it springs forth and takes "from this horizon," hence the eminently Quignardian aphoristic style, which literally arrives at its observations by marking itself off, by creating a boundary (horos), aphorizein.

One could readily claim, then, that the horizon or boundary is there only because there is an eye there to regard it. That is to say, the present does not merely encounter this horizon, but also decisively creates it. The present itself has constituted the horos, which suggests that the past is already contained or lodged in the now. Conversely, the spectacle of the past could be understood as giving birth to the now that arrives to greet it. Quignard's zoomorphic metaphorthe present as the eye of the body that is the past - proposes that the two aspects, the infectum and the perfectum, are organically conjoined, distinct but inseperable, held together by the horizon that gives both sides their definition, their contour. If it is true that the past is already in 
the present, then it also holds that the present is already in the past. Within the vast frame of the horizon, the two aspects of time are bound together.

What permits this boundary, this horizon, to be recognized as such? What is the constitutive exterior that allows the bounded area to be thus identified? What is the ground or the foundation of both the present and the perfected past? It can only be that which is already there, the iam that is beyond the bounded scene, or beyond boundedness itself. The term for the boundlessness that allows the horizon to take shape is the aorist, literally that which negates the horos: a-oriston, "without horizon, without boundary, without limit.” Quignard offers a very concise series of definitions:

To horizon définit ce qui limite ou délimite le site au sein de l'espace. To aoriston, ce qui est sans limites. Ce mot définit ce qui ne connaît pas de frontière et qui ne connaît plus d'horizon. To ek-statikon définit ce qui se tient en dehors de sa place. Ce qui est hors de soi. Le site en extension de toute situation. Le mot ek-statique définit le temps même. ( $S J$ 137)

The aorist is the already that defines both the progressive present, which already contains the past, and the completed past, which already contains the present. It is "ecstatic"; it is "time itself."

The force of the aorist is therefore consolidated in the key term Jadis: "La forme française jadis se décompose comme Ja-a-dis qui peut elle-même se traduire comme Déjà/il y a/des jours. Source qui renvoie à une source qui antécède. C'est ainsi que le Jadis structure le temps comme avant." (SJ 148) As the "fount of time" ("fons temporis," SJ 147), le Jadis can neither be located nor dated. All the same, le Jadis is everywhere, coursing through the paginae of the Dernier royaume, living on or surviving precisely as the non-localizable, as the 
interminable — "Le Jadis erre sur tout l'espace de la terre." ${ }^{, 14}$ For Jean-Luc Nancy, this errancy specifies the meaning of Quignard's provocative neologism, the verb jadir: "Le jadis jadit c'est-à-dire qu'il survient dans sa perte, en tant que perdu, un paradis perdu [...], ainsi toutefois survenant, faisant encontre et rencontre dont au moins il peut trouver, lui, attestation elle-même archaïque."15 Nancy's allusion to "a paradise lost" is relevant, insofar as Quignard evntually turns to theological language, albeit in a throroughly non-Deist fashion. Specifically, he borrows terms from negative theology and the Plotinian method of apophasis, an utterance that reverently refuses to utter anything in positive and therefore reductive terms. In an analogous way, affirming only by means of negating, Quignard elaborates the force of jadis, which is distinguished from the past:

Le jadis par rapport au passé a pour premier trait de ne pas avoir nécessairement été. Le jadis ne figure ni au nombre des étants ni au nombre des ayant été car il n'a pas encore fini de surgir. Le jadis est un puits plus vaste que tout le passé. (SJ 149) Le Jadis participates in the origin that antedates all that is originated. It is prior, already there before the beginning ("Ce qui précède le début, tel est le jadis," SJ 60). That is to say, le Jadis precedes the language and the borders and the limits that define experience through polarization and discrimination. Accordingly, it is linked to the apohatic, alpha-privative terms that Plotinus employs to point (negatively) to the origin: "Alogos, aoristos, apeiros, tels sont les mots de Plotin" (SJ 137). In contrast, the passé is rivetted to the boundaries imposed by language.

The key distinction between le Jadis and the passé is therefore best understood in light of aspectual rather than temporal diffference. The passé is replete with that which has been, with actions completed or perfected from the perspective of the present. For this reason, it is grammatically represented by the "present perfect" or passé composé, whose aspect explicitly 
diverges from the aorist force of the passé simple. The acts that comprise the perfected past do so by being taken from the horizon of lived experience. They are aphoristic. The contents of le Jadis, however, are aoristic, simple. They are associated with a prior, liquid source that does not suffer the cuts, divisions, or contours featured in language's sculpted accomplishments (“Il y a un pressentiment de la préxistence, substantielle, liquide, obscure, ontologique, inconnaissable à la vision, au langage, à la conscience," SJ 249). The aorist surge of le Jadis is without the temporal or spatial boundaries that compose the verbal sense of "present perfect":

L’aoriste est lié à l'achronie. On dit aussi : le passé simple. [...]

Les simples n'opposent pas comme les mots du langage se discriminent et se polarisent. Face à la simplicitas du passé simple, si simple, presque aoristique, il y a un passé composé, si complexe, si composé qu'on peut presque le dire décomposant. C'est le passé du langage. (SJ 127)

Therefore, guided by aspectual difference, we discover that two contrasting types of the past have been operative throughout ("il y a deux sources du temps," SJ 31): there is the past as “irréversibilité” (“le passé-à-jamais”), which Quignard identifies as “deuil”; and the past as "réversibilité," which is characterized as “théophanie," as the limitless ever resurgent past—_Le passé de ce monde comme printemps à faire sans cesse revenir” ( $S J 33)$. This latter past “n’a pas encore fini de surgir." Quite explicitly, Quignard grounds the simple aspect of the aorist in the déjà that resounds in le Jadis and promises an encore: “Il n'y a aucun Jamais-plus dans le Jadis. Il y a un jour. Un jour déjà. Un jour encore.” (SJ 150)

Whereas the simple ontology of le Jadis must be differentiated from the completed, ontic phenomena of the passé, it is important to see some deeper relation between le Jadis and the présent, whose radical transience should also be defined or affirmed negatively, that is, as 
passing constantly between the no longer and the not yet. As Laurence David notes: "Dans le cycle du Dernier royaume, Pascal Quignard dit que le présent n'existe pas. On ne peut penser à la seconde même. Le présent serait tout au plus un passage entre deux intervalles." ${ }^{\text {"16 }}$ In order to distinguish, then, the constitutive negativity of le Jadis from that of le présent, it again appears necessary to stress a difference in verbal aspect. The negative force of le présent is through and through durative or continuous, fluctuating ceaselessly between what has been and what is to come, between mourning and theophany. As cited above, "Le passé est un immense corps dont le présent est l'œil'" (SJ 20); but this past should now be understood in its two, distinct aspects: the irreversible past of the perfect; and the reversible past of the aorist. By means of its continuous movement, le présent, consistently associated with the eyes, can train its gaze either on the limited, visible past or the unlimited, invisible past. In a much earlier text, his "Préface" to Colette Lazam's translation of Apuleius's De Deo Socratis, Quignard privileges the latter option: “Aimer, dormir, lire c'est ce 'voir l'aphantos'. Lire, c'est suivre des yeux la présence invisible." 17 It would appear that the negative constitution of present's durative aspect (no longer, not yet) is precisely what attracts it to the privative substance (alogos, aoristos, apeiros) of le Jadis.

To illustrate, Quignard alludes to the story of Gyges. In the first book of his History, Herodotus relates how the Lydian king, Candaules, eager to confirm that his wife was the most beautiful of women, turned to his trusty bodyguard, Gyges. With some difficulty, Candaules tried to persuade Gyges to spy on her as she undressed for bed, so that in beholding her nakedness, he would agree that there was indeed no one fairer. Yet, Gyges wisely protested: $\alpha \mu \alpha$

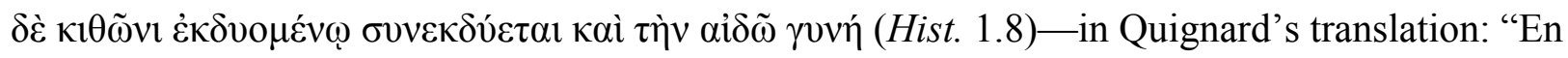
même temps qu'elle se dépouille de sa chemise, reine ou non, la femme quitte sa gêne" (SJ 62). 
Apart from the interpolation ("reine ou non"), which does not appear in Herodotus's Greek, the translation is perfectly accurate and literal. For Quignard, the crucial term of the passage is aidōs, "gêne", which he takes to be an alpha-privative noun: shame is that which should not be seen ( $a$ $i d \bar{s}$ ). Herodotus appears to support this etymology further in the episode, not cited by Quignard, when the queen rebukes Gyges for "seeing what he should not" ('înฺ $\tau \grave{\alpha} \mu \eta \dot{~} \sigma \varepsilon \delta \varepsilon \tilde{\imath}, 1.11)$. In Quignard's text, this brief story yields a series of observations that pursue the path of key negative conceptions, beginning with the word for truth, alètheia, which eradicates forgetfulness (lēthē): "La vérité se disait en grec alêtheia. Est vrai ce qui ne parvient pas à s'oublier. [...]Alêtheia est le Non-oublié comme A-oriston est le Non-fini et comme $A$-idès est le Non-visible" (SJ $62-63)$. Continuing along this line, alêtheia is connected with the Latin revelatio, literally a lifting of the veil, which corresponds to the undressing scene in Herodotus. For Quignard, it is within the logic of revelation that we recognize how the eye of the present relates to the body of the past: "Non-oubli qui arrache le voile sur le passé. La souche du vrai est le nu. C'est encore le mot de Gygès : quand elle se dénude, reine ou non, la femme arrache la vélation sur la zoomorphie" (SJ 63).

In respecting no boundaries, like the line that divides what should and should not be seen, like the border that separates humans from beasts or predators from prey, the aorist aspect is revealed in the present's encounter with the past; not with the past of what has been but rather with the past of what is already there, "le jour déjà": le Jadis. The continuous aspect of the present is interrupted and disrupted by the simplicity of this past which invisibly surges into view. As Simon Saint-Onge expresses it, le Jadis is "un processus de figuration qui fait éclater le continuum de la temporalité." ${ }^{\prime 18}$ To follow with one's eyes this invisible presence is to read the page, the pagina, which becomes the scene of the past as simultaneity, as something all at once, 
"en même temps" and decidedly not as the repository of that which has been completed in the past and will never come again. To refer again to "le mot de Gygès," although Quignard does not call attention to it, Herodotus's adverb, hama, "en même temps," is in fact cognate with the Latin iam that yields the French déjà-dès et jà, de jam. And "at the same time" concisely recalls the effect of returning to the same. It broaches the profound relation between simultaneity and similarity, simul and similis; as well as the simultaneity and similarity evoked in the simple (semel plex) aspect of the aorist (SJ 127).

To return to the same is to wrest the past free from its stable location in History. It is to dissolve its delimitations and thereby return it to time itself. "Les formes sont des limites. Dans la métamorphose les formes ne connaissent plus de limites. Elles sont devenues aorista. Leur horizon est sans forme: c'est le temps" ( $S J$ 139). To return to the same is to remove the veil that consigns the past to a chain of accomplishments, of perfected acts that will never return, acts that have been expelled from living time. Hence, to return to the same is to enjoy the simultaneity and simplicity of the past, the past in its aorist aspect, which overwhelms every limit, unveils itself as the all-at-once, and radiates in its invisibility. In a word, it is to throw an eye onto that which is already there before the beginning, to witness the vivid splendor of the now, to place the present "sur le jadis."

\section{NOTES}

${ }^{1}$ Sigmund Freud, "Das Unheimliche" (1919), in Gesammelte Werke, 18 vols. (Frankfurt am Main: Fischer, 1999), 225 - 268 
${ }^{2}$ On Quignard's indebtedness and reconfiguration of Freudian and Lacanian psychoanalysis, see Chantal Lapeyre-Desmaison, "Pascal Quignard - une poétique de l'agalma," Études françaises 40 (2004), $39-53$.

${ }^{3}$ Pascal Quignard, Petits traités II (Paris: Gallimard, coll. Folio, 1999), back cover.

${ }^{4}$ Jean-Louis Pautrot, Pascal Quignard ou le fonds du monde (Amsterdam-New York: Rodopi, 2007), 9. Pautrot is quoting from Quignard's “Traités sur Esprit.” Jacques Esprit. De la fausseté des vertus humaines. 1678 (Paris: Aubier, 1996), 26.

${ }^{5}$ Again, I cite Pautrot: "Cette œuvre se bâtit à contre-courant de ce que son auteur perçoit comme la doxa de notre époque: paradoxale, donc, au sens que lui conférait Barthes." Pascal Quignard ou le fonds du monde, 8 .

${ }^{6}$ Pascal Quignard, Dernier royaume II: Sur le jadis (2002; Paris: Gallimard, coll. Folio, 2004), 17. Subsequent citations from this edition will be marked in the text as $S J$ with page number. ${ }^{7}$ Across the Dernier Royaume series, Quignard suggests his artistic kinship with Rimbaud, for example in Sordidissimes, where he cites directly from Une Saison en Enfer (Délires II:

Alchimie du Verbe): "Liste d'Arthur Rimbaud : La littérature démodée, latin d'église, livres érotiques sans orthographie, romans de nos aïeules, contes de fées, petits livres de l'enfance." Sordidissimes (Paris: Grasset, 2004), 257. On Quignard's indebtedness to Rimbaud's style, see Gaspard Turin, “"Entre centre et absence' : fragmentation et style chez Pascal Quignard,” Littérature 153 (2009), 86 - 101; especially 92 - 93.

${ }^{8}$ The term enargeia is first found in Dionysius of Halicarnassus, Commentaries on the Attic Orators: Lysias, 7. See also Longinus, On the Sublime 15; and Quintilian's remarks, Institutio oratoria $6.2 .29-32$. 
${ }^{9}$ Émile Benveniste, Problèmes de linguistique générale, vol. 1 (Paris: Gallimard, 1966), 238 42.

${ }^{10}$ Richard Heinze writes: "The more vividly [Vergil] produces the illusion in us that we are facing immediately [unmittelbar] the events themselves, the more perfectly he believes that he has reached his goal. An external feature of his narrative, but a very characteristic one, is the overwhelming use of the historical present $[\ldots]$ intended to paint the events for us as truly present." Virgils epische Technik (1915; Stuttgart: Teubner, 1982), 374 (my emphasis). For a comparative account of the narrative implications of the historical present in Caesar's Gallic Wars and Charles de Gaulle's Mémoires de guerre, see Sylvie Mellet, "Le présent 'historique' ou 'de narration,"” L'Information Grammatticale 4 (1980), 6 - 11.

${ }^{11}$ See, e.g., Paul Hopper, "Some Observations on the Typology of Focus and Aspect in Narrative Language," Studies in Language 3 (1979), 37 - 64

${ }^{12}$ Robert Longacre, "A Spectrum and Profile Approach to Discourse Analysis," Text 1 (1981) $337-59$.

${ }^{13}$ For Quignard's reflections on the relation between vestigium and investigatio, see SJ 67.

${ }^{14}$ Pascal Quignard, Dernier royaume IV: Les Paradisiaques (Paris: Grasset, 2004), 18.

${ }^{15}$ Jean-Luc Nancy, “Jadis, jamais, bientôt (l'amour)," in Pascal Quignard, figures d'un lettré, Philippe Bonnefis and Dolorès Lyotard, ed. (Paris: Galilée, 2005), 383 - 90; here, 384.

${ }^{16}$ Laurence Werner David, "La mémoire la plus lointaine,” Critique 63 (2007) 508 - 19; here, 508.

${ }^{17}$ Pascal Quignard, "Petit traité sur les anges," Preface to Apuleius, Le Démon de Socrate, C. Lazam, trans. (Paris: Payot \& Rivages, 1993), 28. 
${ }^{18}$ Simon Saint-Onge, "Le temps contemporain ou le Jadis chez Pascal Quignard,” Études françaises 44 (2008), 159 - 72; here, 160. 